\title{
DETERMINAN EFEKTIVITAS AUDITOR INTERNAL PEMERINTAH (Studi Pada Kantor Inspektorat Provinsi Maluku Utara)
}

\author{
Irfan Zamzam \\ Suriana AR. Mahdi \\ Universitas Khairun
}

\begin{abstract}
This study examines the determinants of the effectiveness of internal auditors at the Office of the Inspectorate of North Maluku. Specifically, this study tests; influence of professional expertise, quality of work, independence, perceived career path and top management influence of internal auditor on the effectiveness of internal audit. Analysis was conducted by using multiple regression analysis from 43 respondents. The results showed that; Professional expertise, quality of work, independence and career path affect the effectiveness of internal audit while top management support does not influence the effectiveness of internal audit.
\end{abstract}

Keywords: Professional Experience, Work quality, Independence, careers and tackling and top management.

\section{PENDAHULUAN}

Perkembangan demokrasi saat ini, menuntut peran pemerintah semakin transparan dan akuntabel terhadap pengungkapan pengelolaan dana keuangan Negara (Rohman, 2014) untuk mewujudkan good governance agar terciptanya tata kelola pemerintahan yang baik. Menurut Tackie, Yiadom dan Achina (2016) pemerintah sangat berperan penting dalam meningkatkan akuntabilitas, transparansi dan kinerja sektor publik terutama di negara-negara berkembang untuk berbagai pemangku kepentingan, dimana pemerintah bertangggungjawab dalam menjalankan mekanisme kontrol keuangan yang efisien dan efektif.

$\begin{array}{clc}\text { Tuntutan } & \text { masyarakat } & \text { atas } \\ \text { penyelenggaraan } & \text { pemerintahan } & \text { atas }\end{array}$

terwujudnya good dan clean governance semakin meningkat yang menghendaki adanya aparatur pemerintah yang berkompeten pelaksanaan fungsi pengawasan intern yang andal dan sistem pengendalian intern yang baik (Rohman, 2014) bagi profesi akuntan.

Profesi akuntan bertanggungjawab untuk meningkatkan keandalan laporan keuangan perusahaan, sehingga informasi tersebut dapat dijadikan sebagai dasar pengambilan keputusan yang tepat yang menjamin terciptanya good governance, maka audit internal merupakan bagian penting dari struktur organisasi pemerintah (Coram, Ferguson, dan Moroney, 2008). Jika menjalankan fungsi audit internal yang dikonfigurasi dengan baik, audit internal dapat memainkan peran penting dalam 
proses pemerintahan dan akuntabilitas lembaga-lembaga sektor publik melalui penilaian mereka pada efektivitas pengendalian organisasi, tata kelola dan proses manajemen risiko (Asare, 2009). Selain itu, pengawasan internal atas penyelenggaran pemerintah diperlukan untuk mendorong terwujudnya good governance dan clean government serta mendukung penyelenggaraan pemerintahan yang efektif, efisien, transparan, akuntabel serta bersih dan bebas dari praktik korupsi, kolusi dan nepotisme.

Namun pada kenyataannya, peran auditor internal tersebut dianggap belum maksimal dalam menjalankan tugasnya sebagai pengawan dengan dibutikan adanya fenomena yang terjadi pada tahun 2013 bahwa Inspektorat Daerah DKI Jakarta gagal melakukan pengawasan terhadap Satuan Kerja Perangkat Daerah (SKPD) dan Unit Kerja Perangkat Daerah (UPKD yang mengakibatkan muncul berbagai kasus terjadinya penyimpangan, mulai dari proyek bus asal China yang karatan dan rusak, kebocoran lelang kepala sekolah, hingga kasus korupsi oleh sejumlah camat dan lurah. Dengan adanya kasus seperti ini dapat disinyalir bahwa masih buruknya kualitas audit yang dihasilkan oleh Inspektorat Daerah DKI Jakarta karena berbagai macam kasus penyimpangan belum dapat terdeteksi secara dini yang mengakibatkan praktik KKN di lingkungan
Pemerintah Daerah DKI Jakarta masih berlaku (http//www.indopos.co.id).

Berdasarkan fenomena tersebut di atas menunjukan bahwa evektifitas internal audit dalam menjalankan tugasnya sebagai pengawasannya terhadap pemerintah masih terlihat minim, sehingga perlu untuk dilakukan pengkajian secara mendalam untuk mengetahui sejauh mana tingkat evektifitas auditor internal dalam menjalankan tugasnya. Oleh karena itu, auditor internal harus memiliki keahlian profesional, pendidikan dan pelatihan yang berkelanjutan, sikap independensi yang tinggi, serta kualitas kerja yang baik, sehingga dalam menjalankan tugasnya auditor internal dapat memberikan pendampingan peningkatan kepada pemerintah dalam pengelolaan keuangan negara yang efektif, efisien, transparan, dan akuntabel sesuai dengan amanat Peraturan Pemerintah Nomor 60 tahun 2008.

Beberapa peneliti terdahulu mengkaji tentang faktor-faktor yang berpengaruh terhadap efektivitas audit internal sebagai berikut; Arena dan Azzone, 2009) D'Onza, Selim, Melville, dan Allegrini (2015), yang hasil penelitiannya menyatakan bahwa independensi berpengaruh terhadap efektivitas audit internal. Cohen dan Sayag (2010) hasil penelitiannya menunjukan bahwa karir dan penjenjangan tidak berpengaruh terhadap efektivitas audit internal, namun manajemen puncak 
berpengaruh terhadap efektivitas audit internal.

Berbeda dengan Penelitian yang dilakukan oleh Tackie, Yiadom dan Achina (2016) menunjukan bahwa kemahiran profesional, Independensi auditor dan karir memiliki hubungan positif dengan Efektivitas audit internal, sedangkan dukungan manajemen puncak tidak berpengaruh terhadap efektivitas audit internal. Selain itu hasil penelitian Rahadhitya dan Darsono (2015), menunjukan hasil bahwa pengalaman auditor, pendidikan, pelatihan berpengaruh terhadap efektivitas audit internal, sedangkan manajemen resiko dan management support tidak berpengaruh terhadap efektivitas audit internal. Sedangkan hasil penelitian Dellail dan Omri (2016) menunjukkan bahwa independensi, objektivitas, dukungan manajemen, penggunaan fungsi audit internal sebagai tempat pelatihan manajemen dan organisasi auditor Internal berpengaruh terhadap efektivitas audit internal.

Adapun penelitian yang dilakukan oleh Mahmudah dan Riyanto (2016) yang menunjukkan hasil bahwa efektivitas sistem pengendalian internal, dukungan manajemen, dan audit profesionalisme berpengaruh signifikan terhadap efektivitas audit internal. Selain itu penelitian yang dilakukan oleh Gamayuni (2016) menunjukkan hasil bahwa kompetensi, dukungan manajemen dan efektivitas fungsi audit internal berpengaruh signifikan terhadap kualitas pelaporan keuangan, sedangkan objektivitas tidak berpengaruh signifikan terhadap kualitas pelaporan keuangan dan selanjutnya penelitian yang dilakukan oleh Anto, Sutaryo dan Payamta (2016) menunjukkan hasil bahwa keahlian profesional, kualitas pekerjaan, independensi organisasi, karir dan penjenjangan, serta dukungan pimpinan entitas berpengaruh signifikan terhadap efektivitas audit internal.

Penelitian ini mengacu pada penelitian yang dilakukan oleh Anto, Sutaryo dan Payamta (2016) dan Tackie, Yiadom dan Achina (2016) dengan perbedaan penelitian terletak pada waktu dan tempat penelitian. Dari uraian latar belakang tersebut di atas, terdapat adanya fenomena dan masih terdapat berbagai perbedaan hasil penelitian, sehingga mendorong peneliti untuk melakukan penelitian dengan judul "Determinan Efektivitas Audit Internal Pemerintah (Studi Pada Kantor Inspektorat Provinsi Maluku Utara)".

\section{Rumusan Masalah dan Tujuan Penelitan}

Sesuai dengan uraian permasalahan dan perbedaan penelitian tersebut di atas, maka rumusan masalah dan tujuan dari penelitian ini untuk menguji: Pertama; Apakah keahlian profesional auditor internal 
berpengaruh terhadap efektivitas audit internal. Kedua; Apakah kualitas kerja auditor internal berpengaruh terhadap efektivitas audit internal. Ketiga; Apakah independensi auditor internal berpengaruh terhadap efektivitas audit internal. Keempat; Apakah karir dan penjenjangan auditor internal berpengaruh terhadap efektivitas audit internal dan Kelima; Apakah dukungan manajemen puncak berpengaruh terhadap efektivitas audit internal.

\section{KERANGKA TEORITIS DAN PENGEMBANGAN HIPOTESIS}

Landasan teori yang digunakan dalam penelitian ini adalah teori atribusi. Teori atribusi dikemukakan untuk mengembangkan penjelasan mengenai cara kita menilai orang secara berlainan, bergantung pada makna apa yang kita kaitkan pada perilaku tertentu. Pada dasarnya, teori ini mengemukakan bahwa bila kita mengamati perilaku individu, kita berusaha menentukan apakah perilaku itu disebabkan oleh faktor internal atau ekternal. Faktor internal adalah perilaku yang diyakini berada dibawah kendali individu itu, sedangkan faktor ekternal adalah dilihat dari hasil sebab-sebab luar, orang itu terpaksa berperilaku demikian oleh situasi (Robbins, 2007: 172).

Menurut Mahdi (2014) Teori atribusi merupakan bagian dari teori keperilakuan yang menjelaskan tentang persepsi sesorang terhadap

lingkungan

yang

mempengaruhinya, dimana persepsi merupakan padangan yang dimiliki oleh seseorang atau beberapa orang melalui sesuatu pengalaman diri yang dapat mempengaruhi sikap dan prilaku orang tersebut Menurut Hudayati (2002) attribution theory dikembangkan oleh Fritz Heider yang mengargumentasikan bahwa perilaku seseorang itu ditentukan oleh kombinasi antara kekuatan internal (internal forces) yaitu faktor-faktor yang berasal dari dalam diri seseorang misalnya kemampuan atau usaha dan eksternal forces yaitu faktor-faktor yang berasal dari luar misalnya task difficulty atau keberuntungan. Berdasarkan hal itu maka seseorang termotivasi untuk memahami lingkungannya dan sebabsebab kejadian tertentu.

Dari uraian tersebut di atas dapat ditegaskan bahwa teori atribusi merupakan teori yang menjelaskan tentang persepsi, dimana persepsi secara umum merupakan sebuah pandangan atau penilaian yang dirasakan berbeda oleh setiap individu yang merespon orang-orang, lembaga ataupun sebuah lingkungan yang mempengaruhinya, baik secara internal maupun secara ekternal (Mahdi, 2012)

\section{Audit Internal}

Menurut Institute of Internal Auditor (The IIA) mencoba untuk lebih memahami 
perkembangannya lingkup praktik audit internal di seluruh dunia (Hass et al 2006) mendefinisikan bahwa;

"Internal auditing is an independent, objective assurance and consulting activity designed to add value and improve an organization's operations. It helps an organization accomplish its objectives by bringing a systematic, disciplined approach to evaluate and improve the effectiveness of risk management, control, and governance process".

Definisi tersebut diatas dapat diartikan bahwa audit internal adalah kegiatan yang memberikan jaminan dan konsultasi independen yang bertujuan untuk memberi nilai tambah dan memperbaiki aktifitas operasi perusahaan, yang dapat membantu sebuah perusahaan untuk mencapai tujuannya dengan memberikan pendekatan sistematis dan disiplin untuk mengevaluasi dan meningkatkan efektivitas manajemen risiko, pengendalian, dan tata kelolah. Menurut Tunggal (2015: 25) audit internal merupakan sarana manajemen untuk mengevaluasi dan memonitor efektivitas sistem pengendalian internal sehingga mampu mencegah terjadinya risiko yang merugikan perusahaan serta mengidentifikasi peluang peningkatan efektivitas dan efesiensi operasional.

Audit internal juga didefinisikan sebagai kegiatan penilaian yang bebas, yang terdapat dalam organisasi, yang dilakukan dengan cara memeriksa akuntansi, keuangan, dan kegiatan lain untuk memberikan jasa bagi manajemen dalam melaksanakan tanggung jawab mereka (Mulyadi, 2009: 211).

\section{Efektivitas Audit Internal}

Efektivitas berasal dari kata efektif yang berarti mempunyai nilai efektif, pengaruh atau akibat, bisa diartikan sebagai kegiatan yang bisa memberikan hasil yang memuaskan, dapat juga bahwa efektivitas merupakan keterkaitan antara tujuan dan hasil yang dinyatakan dengan hasil yang dicapai (Alwi, 2005: 284).

Menurut Anthony dan Vijay (2005: 174) efektivitas adalah segala sesuatu yang berhubungan dengan penentu apakah tujuan perusahaan yang telah ditetapkan telah tercapai. Efektivitas menunjukkan keberhasilan perusahaan dalam merealisasikan tujuan perusahaannya. Selanjutnya efektivitas menurut Maman (2007: 65) merupakan hasil prestasi yang dicapai suatu organisasi. Jadi dapat diartikan sebagai keberhasilan dalam mencapai tujuan. Selain itu efektivitas diartikan juga sebagai pengukuran keberhasilan dalam pencapaian tujuan-tujuan yang telah ditentukan (Tugiman, 2011:56).

Menurut Kommarudin (2010: 269) efektivitas audit diartikan sebagai penerapan Statement of Responsibility of Internal Audit berupa analisis, penilaian, rekomendasi, 
konseling dan informasi yang berhubungan dengan aktivitas yang direview untuk membantu setiap auditor dalam melaksanakan tugasnya.

Atribusi efektivitas internal auditor terdiri dari; Pertama: Keahlian Profesional Auditor Internal; keahlian profesional sebagai kompetensi teknis, yaitu kompetensi yang harus dimiliki oleh seorang auditor baik dalam bidang auditing, akuntansi, administrasi pemerintahan maupun ilmu komunikasi (Awaluddin, 2013). Sedangkan menurut Wibowo (2007: 86) kemampuan (ability) atau kapasitas seseorang untuk mengerjakan berbagai tugas dalam suatu pekerjaan, dimana kemampuan ini ditentukan oleh 2 (dua) faktor yaitu kemampuan intelektual dan kemampuan fisik (Robbins dan Coutler, 2007: 38).

Kedua; Kualitas Kerja Auditor; Kualitas audit dapat pula ditunjukkan dengan ketaatan pada standar audit yang berlaku sehingga kehandalan pekerjaannya dapat terjaga (Singgih dan Bawono, 2010), sedangkan Cohen dan Sayag (2010) menjelaskan bahwa ketika audit internal bekerja menggunakan standar profesional audit yang berlaku, maka kegiatan audit internal juga akan memberikan nilai tambah bagi auditan. Ketiga; Independensi; Menurut Islahuzzaman (2012: 179) auditor yang independen adalah auditor yang tidak dipengaruhi oleh berbagai kekuatan yang berasal dari luar diri auditor dalam mempertimbangkan fakta yang dijumpainya dalam audit. Independensi lebih banyak ditentukan faktor luar diri auditor.Jika akuntan tersebut tidak independen terhadap kliennya, maka opininya tidak akan memberikan tambahan apapun (Mautz dan Sharaf, 1999: 246). Keempat; Karir dan Penjenjangan Auditor; Menurut Irianto (2011: 94) pengertian karir meliputi elemenelemen obyektif dan subyektif. Elemen obyektif berkenan dengan kebijakankebijakan pekerjaan atau posisi jabatan yang ditentukan organisasi, sedangkan elemen subyektif menunjuk pada kemampuan seseorang dalam mengelola karir dengan mengubah lingkungan obyektif. Karir adalah semua jabatan (pekerjaan) yang mempunyai tanggung jawab individu (Ekaningrum, 2007:258). Menurut Cohen dan Sayag (2010) kesempatan karir yang tersedia menyebabkan seorang auditor internal akan berusaha lebih keras untuk menampilkan kinerja yang lebih baik dengan tujuan meningkatkan peluang promosinya. Dan Kelima; Dukungan Manajemen Puncak; Dukungan manajemen terhadap keberadaan auditor internal perusahaan sebaiknya tidak hanya sebatas pada eksistensi strategis departemen audit internal di dalam struktur organisasi. Wujud dukungan manajemen yang lebih penting adalah ketidakberadaan intervensi manajemen terhadap temuan-temuan dari auditor internal (Ferdinand, 2011). 
Dukungan manajemen yang baik diharapkan dapat meningkatkan kinerja auditor internal dan kinerja perusahaan secara keseluruhan.

\section{PENGEMBANGAN HIPOTESIS}

\section{Keahlian Profesional Auditor Internal}

\section{dan Efektivitas Audit Intenal}

Auditor internal dinyatakan memiliki keahlian profesional, jika memiliki kompetensi yang baik. Dimana kompetensi merupakan kualifikasi yang dibutuhkan oleh auditor untuk melaksanakan audit dengan benar. Secara konseptual kompetensi yang tinggi yang dimiliki pemeriksa akan memberikan kualitas hasil pemeriksaan yang baik (Rai, 2008). Menurut Agoes (2005: 227) orang-orang yang profesional, memiliki keahlian, bisa bersifat objektif dan mempunyai integritas serta loyalitas yang tinggi dapat menghasilkan internal audit yang efektif. Apabila audit internal dapat memberikan hasil dan dampak tersebut, maka dapat dikatakan audit internal telah efektif Anto, Sutaryo dan Payamta (2016)

Penjelasan tersebut di atas diperkuat dengan penelitian Arianto (2010); Anto, Sutaryo dan Payamta (2016); Tackie, Yiadom dan Achina (2016) menunjukan bahwa kemahiran profesional, berpengaruh signifikan terhadap efektivitas audit internal. Berdasarkan penjelasan konsep di atas dan hasil penelitian terdahulu tersebut di atas, maka hipotesis penelitian ini adalah:
$\mathrm{H}_{1}=$ Keahlian Profesional Auditor Internal berpengaruh terhadap Efektivitas Audit Intenal

\section{Kualias Kerja Auditor Internal dan Efektivitas Audit Internal \\ Kualitas pekerjaan audit dapat dilihat} dari sisi perencanaan audit, lingkup audit, kewenangan audit serta pengawasan atas pelaksanaan tindak lanjut atas rekomendasi audit. Dengan menjaga kualitasnya, maka auditor juga akan menjaga kredibilitas dan kepercayaan dari pihak auditan, sehingga dapat menjalankan peran audit internal yang efektif (Anto, Sutaryo dan Payamta, 2016). Kualitas pekerjaan audit mempunyai hubungan atau korelasi dengan efektivitas audit internal (Cohen dan Sayag, 2010).

Penjelasan tersebut di atas diperkuat dengan penelitian Arianto (2010); Anto, Sutaryo dan Payamta (2016); Tackie, Yiadom dan Achina (2016) membuktikan bahwa kualitas kerja berpengaruh terhadap efektivitas audit internal. Berdasarkan penjelasan konsep dan Hasil penelitian terdahulu tersebut di atas, maka hipotesis penelitian ini adalah:

$$
\begin{aligned}
\mathrm{H}_{2}= & \text { Kualitas Kinerja Auditor Internal } \\
& \text { berpengaruh terhadap Efektivitas } \\
& \text { Audit Intenal }
\end{aligned}
$$

\section{Independensi Auditor Internal dan Efektivitas Audit Internal}

Independensi adalah hal yang sangat penting untuk menjamin pelaksanaan fungsi 
audit internal yang efektif (Tunggal, 2015: 25). Internal audit juga diharapkan menjadi entitas yang independen. Auditor yang dapat menjaga independensinya maka kredibilitas pekerjaannya tidak akan diragukan lagi, sehingga audit internal memberikan dampak perbaikan bagi auditan dan dapat dikatakan audit internal telah efektif dalam menalankan tugasnya terhadap auditee (Anto, Sutaryo dan Payamta, 2016).

Penjelasan tersebut di atas diperkuat dengan penelitian Arianto (2010); Cohen dan Sayag (2010); Anto, Sutaryo dan Payamta (2016); Tackie, Yiadom dan Achina (2016); Dellai dan Omri (2016) menunjukkan bahwa independensi auditor berpengaruh signifikan terhadap efektivitas audit internal. Berdasarkan penjelasan konsep dan Hasil penelitian terdahulu tersebut di atas, maka hipotesis penelitian ini adalah:

\section{$\mathrm{H}_{3}=$ Independensi Auditor Internal berpengaruh terhadap Efektivitas Audit Internal}

\section{Karir dan Pejenjangan Auditor Internal dan Efektivitas Audit Internal}

Menurut Ekaningrum (2007: 256) karir tidak lagi diartikan sebagai adanya penghargaan institusional dengan meningkat kan kedudukan dalam hirarki formal yang sudah ditetapkan dalam organisasi. Dalam paradigma tradisional, pengembangan karir sering dianggap sinonim dengan persiapan untuk mobilitas kejenjang lebih tinggi, se hingga karir akan mendukung efektivitas individu dan organisasi dalam mencapai tujuannya. Cohen dan Sayag (2010) menjelaskan bahwa kesempatan karir yang tersedia menyebabkan seorang auditor internal akan berusaha lebih keras untuk menampilkan kinerja yang lebih baik dengan tujuan meningkatkan peluang promosinya.

Penjelasan tersebut di atas diperkuat dengan dengan hasil penelitian Tackie, Yiadom dan Achina (2016); Anto, Sutaryo dan Payamta (2016) menunjukkan bahwa karir dan penjenjangan berpengaruh signifikan terhadap efektivitas audit internal. Berdasarkan penjelasan konsep dan Hasil penelitian terdahulu tersebut di atas, maka hipotesis penelitian ini adalah:

$\begin{aligned} \mathrm{H}_{4}= & \text { Karir dan Penjenjangan Auditor } \\ & \text { Internal berpengaruh terhadap } \\ & \text { Efektivitas Audit Intenal }\end{aligned}$

\section{Dukungan Manajemen Puncak dan Efektivitas Audit Internal}

Setiap oganisasi dalam usaha mencapai tujuan dan mengukurnya sampai sejauh mana keberhasilan yang dapat dicapai, dan itu memerlukan dukungan manajemen puncak. Menurut Agoes (2005: 227) agar dapat memiliki departemen audit yang efektif harus ada dukungan yang kuat dari manajemen puncak. 
Penjelasan tersebut di atas dibuktikan oleh penelitian Mahmudah dan Riyanto (2016) yang menunjukkan hasil bahwa dukungan manajemen puncak berpengaruh signifikan terhadap efektivitas audit internal. Tetapi dalam penelitian Rahadhitya dan Darsono (2015) menunjukkan hasil bahwa management support tidak berpengaruh signifikan terhadap efektivitas audit internal. Namun hasil penelitian. Cohen dan Sayag (2010); Anto, Sutaryo dan Payamta (2016); Mahmudah dan Riyanto (2016); Gamayuni (2016); Dellai1 dan Omri (2016) menunjukkan bahwa dukungan manajemen puncak berpengaruh signifikan terhadap efektivitas audit internal. Berdasarkan penjelasan konsep dan Hasil penelitian terdahulu tersebut di atas, maka hipotesis penelitian ini adalah:

$$
\begin{aligned}
\mathrm{H}_{5}= & \text { Dukungan Manajemen Puncak } \\
& \text { berpengaruh terhadap Efektivitas } \\
& \text { Audit Intenal }
\end{aligned}
$$

\section{METODELOGI PENELITIAN}

\section{Pendekatan peneltian, Penentuan Populasi Sampel}

Penenlitian ini merupakan penelitian deskriptif yaitu penelitian menjelaskan fenomena dalam bentuk hubungan causal research. Sampel pada penelitian ini menggunakan metode sempel jenuh, dimana seluruh populasi dijadikan sebagai yaitu 43 Auidor Inspektorat Provinsi Maluku Utara.

\section{Teknik Pengumpulan Data Dan Definisi}

\section{Operasional Variabel}

Data yang digunakan pada penelitian ini menggunakan data primer. Data yang digunakan dalam penelitian ini adalah dengan menggunakan kuesioner/pertanyaan dengan tujuan untuk mengumpulkan informasi dari auditor sebagai responden dalam penelitian ini.

Variabel dependen pada penelitian ini adalah efektifitas audit internal, yaitu auditor yang melaksanakan tupoksi dengan efektif, dengan cara mempersiapkan Kertas Kerja Pemeriksaan (KKP), melaksanakan perencanaan dan koordinasi audit, dan penilaian efektivitas tindak lanjut audit, serta konsistensi laporan audit. Dengan menggunakan 5 instrumen pertanyaan dengan 5 skala likert.

Variabel Independen pada penelitian ini adalah; Pertama; Keahlian Profesional Auditor Internal yaitu Auditor harus mempunyai pengetahuan, keterampilan, dan kompetensi lainnya yang diperlukan untuk melaksanakan tanggung jawabnya. Instrumen yang digunakan bersumber dari 5 indikator pertanyaan dengan 5 skala likert. Kedua; Kualitas Kerja Auditor Internal yaitu Auditor harus menghasilkan kinerja yang baik dan harus banyak memberi kontribusi kepada organisasi. Instrumen yang digunakan 4 indikator pertanyaan dengan 5 skala likert. Ketiga; Independensi Auditor Internal yaitu Auditor harus 
memiliki sikap mental dan tidak bias serta menghindari kepentingan dalam merencanakan dan melaporkan pekerjaan yang dilakukannya. Instrumen yang digunakan bersumber 4 indikator pertanyaan dengan 5 skala likert. Keempat; Karir dan Penjenjangan Auditor Internal yaitu Auditor harus meningkatkan kinerja karir, sikap karir, adaptabilitas karir, dan identitas karir dalam bekerja agar mendapatkan kesempatan karir. Instrumen yang digunakan 4 indikator pertanyaan dengan 5 skala likert. Kelima; Dukungan Manajemen Puncak yaitu Pihak yang bertanggungjawab atas penyediaan dalam bentuk apapun yang dapat digunakan untuk kelancaran pelaksanaan tugas dan tanggungjawab audit internal. Instrumen yang digunakan 4 indikator pertanyaan dengan 5 skala likert.

\section{Metode Analisis Data}

Metode yang digunakan dalam penelitian ini adalah analisis regresi linear berganda untuk melihat pengaruh variabel independen terhadap variabel dependen. Metode analisis dalam penelitian ini menggunakan bantuan perhitungan malalui SPSS 17.0. Uji hipotesis. Bentuk Model persamaan ini antara lain:

$Y=a+b_{1} \cdot X_{1}+b_{2} \cdot X_{2}+b_{3} \cdot X_{3}+b_{4} \cdot X_{4}+b_{5} \cdot X_{5}+\varepsilon \ldots$

Keterangan:
$\mathrm{Y}=$ Efektivitas audit internal

$\mathrm{a}=$ Konstanta

$\mathrm{b}=$ Koefesien regresi

$\mathrm{X}_{1}=$ Keahlian profesional auditor internal

$\mathrm{X}_{2}=$ Kualitas kerja auditor internal

$\mathrm{X}_{3}=$ Independensi auditor internal

$\mathrm{X}_{4}=$ Karir dan penjenjangan auditor internal

$\mathrm{X}_{5}=$ Dukungan manajemen puncak

$\varepsilon=$ Error

\section{HASIL PENELITIAN DAN PEMBAHASAN}

\section{Tingkat Pengembalian Kuisioner}

Dalam penelitian ini peneliti menyebarkan kuesioner pada 43 orang auditor/pemeriksa Inspektorat Provinsi Maluku Utara. Dari kuesioner yang disebarkan, kuesioner yang kembali sebanyak 38 atau sebesar $88,37 \%$ dan kuesioner yang tidak kembali sebanyak 5 atau $11,63 \%$.

\section{Hasil Pengujian Hipotesis}

Hasil uji regresi liner berganda dapat dilihat pada tabel 1:

Pada model regresi ini, nilai konstanta yang tercantum sebesar 2,147 dapat diartikan jika variabel bebas dalam model diasumsikan sama dengan nol, secara rata-rata variabel diluar model tetap akan meningkatkan efektivitas audit sebesar 2,147 . 


\section{Tabel 1. Ringkasan Hasil Uji Koefisien Regresi Terhadap Determinan Efektifitas Auditor Internal}

\begin{tabular}{|c|c|c|c|c|}
\hline Model & B & $\mathbf{t}$ & Sig & Ket \\
\hline (Constant) & 2.147 & 3.927 & .000 & - \\
\hline Keahlian Profesional_ $\mathrm{X}_{1}$ & .293 & 2.250 & .031 & H1 Diteriima \\
\hline Kualitas Kerja_X $X_{2}$ & -.404 & -2.067 & .047 & H2 Diteriima \\
\hline Independensi_X ${ }_{3}$ & .429 & 3.931 & .000 & H3 Diteriima \\
\hline Karir Dan Penjenjangan_X $\mathrm{X}_{4}$ & .167 & .870 & .391 & H4 Ditolak \\
\hline Dukungan Manajemen Puncak_X5 & -.017 & -.221 & .827 & H5 Ditolak \\
\hline
\end{tabular}

$P$ Value $=0,05$, Adjusted R Square $=0,423, t$ tabel $=2.037$

Sumber; Diolah, peneliti, 2017

$$
\mathrm{Y}=2,147+0,293 \mathrm{KP}+-0,404 \mathrm{KK}+0.429 \mathrm{I}+0.167 \mathrm{KDP}+-0.017 \mathrm{DMP}+\varepsilon
$$

Keahlian Profesional Auditor Internal

\section{Dan Efektivitas Audit}

Hipotesis $\mathrm{H}_{1}$ menyatakan bahwa keahlian profesional auditor internal berpengaruh terhadap efektivitas audit internal. Hasil pengujian hipotesis ini menunjukkan bahwa keahlian profesional memiliki nilai $t$ hitung 2,250 >t tabel 2,037 dengan tingkat signifikansi sebesar $0.031<$ 0.05. Hasil penelitian ini menunjukkan bahwa keahlian profesional auditor internal berpengaruh terhadap efektivitas audit internal, sehingga hasil penelitian ini sejalan dengan penelitian Arianto (2010); Anto, Sutaryo dan Payamta (2016); Tackie, Yiadom dan Achina (2016) menunjukan bahwa kemahiran profesional, berpengaruh signifikan terhadap efektivitas audit internal.

Secara konseptual kompetensi yang tinggi yang dimiliki pemeriksa akan memberikan kualitas hasil pemeriksaan yang baik. Selanjutnya menurut Agoes

(2005: 227) orang-orang yang profesional, memiliki keahlian, bisa bersifat objektif dan mempunyai integritas serta loyalitas yang tinggi dapat menghasilkan internal audit yang efektif.

\section{Kualitas Kerja Auditor Internal Dan} Efektivitas Audit Internal

Hipotesis $\mathrm{H}_{2}$ menyatakan bahwa kualitas kerja auditor internal berpengaruh terhadap efektivitas audit internal. Hasil pengujian hipotesis menunjukkan bahwa kualitas kerja auditor memiliki nilai $t$ hitung $-2,167>t$ tabel 2,037 dengan tingkat signifikansi sebesar $0.037<0.05$. Hasil penelitian ini menunjukkan bahwa kualitas kerja auditor internal berpengaruh terhadap efektivitas audit internal, sehingga $\mathrm{H}_{2}$ diterima. Hasil penelitian ini sejalan dengan penelitian penelitian Arianto (2010); Anto, Sutaryo dan Payamta (2016); Tackie, Yiadom dan Achina (2016) membuktikan bahwa kualitas kerja berpengaruh terhadap efektivitas audit internal. 
Hasil penelitian juga memperkuat penelitiani Cohen dan Sayag (2010) yang menyatakan kualitas pekerjaan audit mempunyai hubungan atau korelasi dengan efektivitas audit internal. Selanjutnya oleh Mihret dan Yismaw (2007) yang menjelaskan bahwa salah satu faktor bagi efektivitas audit internal adalah kualitas audit internal yang ditunjukkan dengan kemampuannya menyediakan temuan dan rekomendasi audit yang berguna bagi auditan.

\section{Independensi Auditor Internal Dan}

\section{Efektivitas Audit}

Hipotesis $\mathrm{H}_{3}$ menyatakan bahwa independensi auditor internal berpengaruh terhadap efektivitas audit internal. Hasil pengujian hipotesis menunjukkan bahwa Independensi memiliki nilai $t$ hitung $3,931>t$ tabel 2,037 dengan tingkat signifikansi sebesar $0.000<0.05$. Hasil penelitian ini menunjukkan bahwa independensi auditor internal berpengaruh terhadap efektivitas audit internal, sehingga $\mathrm{H}_{3}$ diterima. Hasil penelitian ini sejalan dengan penelitian yang dilakukan oleh penelitian Arianto (2010); Cohen dan Sayag (2010); Anto, Sutaryo dan Payamta (2016); Tackie, Yiadom dan Achina (2016) ; Dellai1 dan Omri (2016) yang menunjukkan bahwa independensi berpengaruh positif terhadap efektivitas audit.
Manurut Tunggal (2015: 25) independensi adalah hal yang sangat penting untuk menjamin pelaksanaan fungsi audit internal yang efektif. Selanjutnya Gansberg (2005) juga memberi penekanan bahwa untuk menjadi efektif, internal audit harus menjadi organisasi yang independen.

\section{Karir , Penjenjangan Auditor Internal}

\section{Dan Efektivitas Audit}

Hipotesis $\mathrm{H}_{4}$ menyatakan bahwa karir dan penjenjangan auditor internal berpengaruh terhadap efektivitas audit internal. Hasil pengujian hipotesis menunjukkan bahwa karir dan penjenjangan Auditor internal memiliki nilai $t$ hitung $-0,870<t$ tabel 2,037 dengan tingkat signifikansi sebesar $0.31>0.05$. Hasil penelitian ini menunjukkan bahwa karir dan penjenjangan auditor internal tidak berpengaruh terhadap efektivitas audit internal, sehingga $\mathrm{H}_{4}$ ditolak. Hasil penelitian ini tidak sejalan dengan hasil penelitian Tackie, Yiadom dan Achina (2016); Anto, Sutaryo dan Payamta (2016) yang menunjukkan bahwa karir dan penjenjangan berpengaruh terhadap efektivitas audit.

Manurut Ekaningrum (2007:256) dalam paradigma tradisional, pengembangan karir sering dianggap sinonim dengan persiapan untuk mobilitas kejenjang lebih tinggi, sehingga karir akan mendukung efektivitas individu dan 
organisasi dalam mencapai tujuannya. Selanjutnya Cohen dan Sayag (2010) yang menjelaskan bahwa kesempatan karir yang tersedia menyebabkan seorang auditor internal akan berusaha lebih keras untuk menampilkan kinerja yang lebih baik dengan tujuan meningkatkan peluang promosinya.

\section{Dukungan Manajemen Puncak Dan}

\section{Efektivitas Audit}

Hipotesis $\mathrm{H}_{5}$ menyatakan bahwa dukungan manajemen puncak berpengaruh positif terhadap efektivitas audit internal. Hasil pengujian hipotesis menunjukkan bahwa Dukungan Manajemen Puncak memiliki nilai $t$ hitung $0,221<t$ tabel 2,037 dengan tingkat signifikansi sebesar 0.827> 0.05. Hasil penelitian menunjukkan bahwa dukungan manajemen puncak tidak berpengaruh terhadap efektivitas audit internal, sehingga $\mathrm{H}_{5}$ ditolak. Hasil penelitian ini tidak sejalan dengan penelitian Cohen dan Sayag (2010); Anto, Sutaryo dan Payamta (2016); Mahmudah dan Riyanto (2016); Gamayuni (2016); Dellai1 dan Omri (2016) Namun hasil penelitian ini sejalan dengan penelitiannya Rahadhitya dan Darsono (2015) menunjukkan hasil bahwa management support tidak berpengaruh signifikan terhadap efektivitas audit internal.

Manurut Agoes (2005: 227) oganisasi dalam usaha mencapai tujuan dan mengukurnya sampai sejauh mana keberhasilan yang dapat dicapai, dan itu memerlukan dukungan manajemen puncak. Selanjutnya agar dapat memiliki departemen audit yang efektif harus ada dukungan yang kuat dari manajemen puncak.

\section{KESIMPULAN DAN SARAN}

Berdasarkan pembahasan hasil penelitian, maka dapat ditarik kesimpulan bahwa, secara parsial: Keahlian profesional auditor internal berpengaruh signifikan terhadap efektivitas audit internal, Kualitas kerja auditor internal berpengaruh signifikan terhadap efektivitas audit internal, Independensi auditor internal berpengaruh signifikan terhadap efektivitas audit internal, Karir dan penjenjangan auditor internal tidak berpengaruh signifikan terhadap efektivitas audit internal dan Dukungan manajemen puncak tidak berpengaruh signifikan terhadap efektivitas auditinternal.

Pada penelitian terdapat beberapa keterbatasan yaitu; Pertama; Pada penelitian ini objek yang diteliti hanya pada satu Instansi yaitu Inspektorat Provinsi Maluku Utara, olehnya itu bagi peneliti selanjutnya dapat mengambil objek penelitian lebih dari satu Inspektorat atau seluruh Inspektorat se Maluku Utara. Kedua; Dalam penelitian ini hanya menggunakan kuesioner, sehingga masih 
ada kelemahan-kelemahan yang ditemui, olehnya itu bagi peneliti selanjutnya dapat menambah teknik wawancara. Ketiga; Dalam penelitian ini variabel yang digunakan untuk mengukur efektivitas audit hanya variabel keahlian profesional, kualitas kerja, independensi, karir dan penjenjangan dan dukungan manajemen puncak. Masih banyak lagi faktor lain yang dapat mempengaruhi efektivitas audit, oleh sebab itu, bagi peneliti selanjutnya dapat meneliti faktor-faktor yang lain selain faktor-faktor yang telah diteliti dalam penelitian ini.

Implikasi penelitian secara kosep adalah selain membuktikan bahwa Keahlian profesional auditor internal, Kualitas kerja auditor internal, Independensi auditor internal berpengaruh terhadap efektifitas auditor internal. Penelitian ini juga mendukung beberapa penelitian terdahulu dan memberikan usulan masukan yang terkait dengan faktor penentu efektifitas internal audit pada Inspektorat Provinsi Maluku Utara.

\section{DAFTAR PUSTAKA}

Agoes, Sukrisno. (2005). Internal Audit Departemen, Enterprises Risk Manajement, dan Good Corporate Governance. Disajikan pada Pidato Pengukuhan Guru Besar Tetap Ilmu Akuntansi. Salemba Empat.

Alwi Hasan, dkk. 2005. Kamus Besar Bahasa Indonesia. Jakarta : Departemen Pendidikan Nasional Balai Pustaka.
Anthony, Robert N dan Vijay, Govindarajan. 2005. Sistem Pengendalian Manajemen. Salemba Empat. Jakarta

Anto, Arifudin Tri. Sutaryo. dan Payamta. 2016. Determinan Efektivitas Audit Internal Pemerintah di Indonesia. Simposium Nasional Akuntansi XIX Lampung. 2016.

Arena, Marika dan Giovanni Azzone. 2009. Identifying Organizational Drivers of Internal Audit Effectiveness. Pacific Accounting Review, 22(3): 224-252

Arianto, Tomi. 2010. Pengaruh Kompetensi, Independensi, Kemahiran Profesional Dan Motivasi Auditor Terhadap Kualitas Audit. Skripsi UIN Syarif Hidayatullah Jakarta.

Asare, Thomas. 2009. Internal Auditing in the Public Sector: Promoting Good Governance and Performance Improvement. International Journal on Governmental Financial Management, 9(1): 15-512.2.3

Awaluddin, Murtiadi. 2013. Pengaruh Independensi dan Kompetensi Auditor Terhadap Kepuasan Kerja dan Kinerja Auditor Inspektorat Kota Makassar. Jurnal ASSETS, 3(2): 146159

Cohen, Aaron dan Sayag, Gabriel. 2010. The Effectiveness of Internal Auditing: An Empirical Examination of its Determinants in Israeli Organisations. Australian Accounting Review, 54(20): 296-307

Coram, Paul, Colin Ferguson, dan Robyn Moroney. 2008. Internal Audit, Alternative Internal Audit Structures and the Level of Misappropriation of Assets Fraud. Accounting and Finance, 48: 543-559 
Dellai, Hella dan Omri, Mohamed Ali Brahim. 2016. Factors Affecting the Internal Audit Effectiveness in Tunisian Organizations. Research Journal of Finance and Accounting. Vol.7, No.16

Ekaningrum, Indri F. 2007. The Boundaryless Career Pada Abad ke-21. Jurnal Visi (Kajian Ekonomi manajemen dan Akuntansi). Vol. IX. No.1 Februari 2002. FE Unika Soegijapranata Semarang.

Tackie, George; Yiadom ,Edward Marfo and Achina ,Sampson Oduro.2016.Determinants of Internal Audit Effectiveness in Decentralized Local Government Administrative Systems. International Journal of Business and Management; Vol. 11, No. 11;

Gamayuni, Rindu, R. 2016.Efektivitas Fungsi Audit Internal: Faktor yang mempengaruhi, dan Implikasinya terhadap Kualitas Pelaporan Keuangan. Simposium Nasional Akuntansi XIX Lampung. 2016Ferdinand, G.M., 2011. "Tantangan Auditor Perusahaan". Makalah Seminar Nasional Universitas Negeri Jakarta 12 Maret 2011.

Hudayati, Ataina. 2002. Perkembangan penelitian akuntansi Keperilakuan: berbagai teori dan pendekatan yang melandasi, JAAI, Vol. 6, No. 2, pp.81-96.

Hass, S. Abdolmohammadi, M.J.,\&Burnaby, P. (2006).The Americas literature review on internalauditing.Managerial Auditing Journal, Vol. 21 No. 8, pp. 835-44.
Irianto, J. 2011. Isu-Isu Strategis Pengembangan Sumber Daya Manusia. Insan Cedekia. Surabaya.

Islahuzzaman. 2012. Istilah-istilah Akuntansi \& Auditing. Edisi Kesatu. Bumi Aksara. Jakarta.

Kommarudin, Ahmad. (2010). Dasar-dasar Manajemen Modal Kerja. PT. Rineka Cipta. Jakarta.

Mahmudah, Hadi. dan Riyanto, BambangLS. 2016. Keefektifan Audit Internal Pemerintah Daerah. Jurnal Akuntansi/Volume XX, No. 01, Januari 2016: 33-51.

Mahdi, Suriana AR. 2012. Analisis Determinan Kualitas Audit Dengan Moral Judgmen Sebagai variabel moderasi, Tesis tidak dipublikasikan, Universitas Brawijaya. Malang

Mahdi, Suriana AR. 2014. Analisis Determinan Kualitas Audit Dengan Moral Judgmen Sebagai variabel moderasi, Jurnal Akuntansi \& Auditing Volume 11/No. 1

Maman, Ukas. (2007). Manajemen, Prinsip dan Aplikasi. Ossa Prom. Bandung.

Mautz, R.K. dan H.A. Sharaf. 1999. The Philosophy of Auditing. American Accounting Association. Sarasota.

Mulyadi. 2009. Auditing. Buku Satu. Edisi Enam. Salemba Empat. Jakarta.

Rai, A. Gusti. 2008. Audit Kinerja Pada Sektor Publik: Konsep Praktik Studi Kasus. Penerbit: Salemba Empat.

Robbins, Stephen.P. 2007. Organizational Behavior, Tenth Edition, Molan, Benyamin (penerjemah). Prilaku Organisasi, PT Macana Jaya Cemerlang. Jakarta. 
Rohman, Abdul Annisa Parasayu.2014.

Analisis faktor-faktor yang mempengaruhi kualitas hasil audit internal (studi persepsi aparat intern pemerintah kota surakarta dan kabupaten boyolali), Diponegoro Journal of Accounting, Volume 3 , nomor 2; hal 1-10

Singgih, E.M dan Bawono, Icuk, R. 2010. Jurnal. Pengaruh Independensi, Pengalaman, Due Care Profesional Terhadap Kualitas Audit. SNA 13 UNSOED. Purwokerto.

Tugiman, Hiro. 2011. Standar Profesional Auditor Internal. Edisi Kelima. Kanisius. Jakarta.

Tunggal, A. Widjaja. 2015. Memahami Internal Dan Operational Auditing. Penerbit Hervarindo. Jakarta.

Wibowo. 2007. Manajemen Kinerja. PT. Raja Grafindo Parsada: Jakarta.

http:www//m.indopos.co.id, Diakses, Rabu, 01 Maret 2017 10: 30 WIT 